\title{
SYSTEMATIC REVISION OF THE SOUTH AMERICAN SPECIES OF PINGUIPEDIDAE (TELEOSTEI, TRACHINOIDEI)
}

\author{
lerecê L. Rosa ${ }^{1}$ \\ Ricardo S. Rosa ${ }^{1}$
}

\begin{abstract}
Five genera of marine fishes are recognized in the family Pinguipedidae: Pinguipes, Prolatilus, Pseudopercis, Paraperci and Kochichthys, the first three being endemic to South America. The following South American pinguipedid species are considered valid: Pinguipes brasilianus, Pinguipes chilensis, Prolatilus jugularis, Pseudopercis numida, Pseudopercis semifasciata and Parapercis dockinski. Lectotypes are designated for Pinguipes brasilianus, Pinguipes chilensis and Prolatilus jugularis.

KEY WORDS. Teleostei, Pinguipedidae, South America, revision
\end{abstract}

The trachinoid family Pinguipedidae Günther, 1860, previously known as Mugiloididae (see RosA \& Rosa 1987), includes poorly known demersal marine fishes found in subtropical and temperate coasts of South America, Africa, Indo West Pacific, Red Sea, and Sea of Japan. Eleven nominal genera (Pinguipes, Mugiloides, Myxonum, Prolatilus, Porteridia, Parapercis, Neopercis, Parapercichthys, Pseudopercis, Cheimarrichthys and Kochichthys) and nearly sixty species have been included in the family. However, its monophyly has never been clearly established, and the interrelationships of its genera remain uncertain.

Data on the suprafamilial interrelationships of the Pinguipedidae are scanty. GoSLINE (1968) placed the family near the basal percoids; ROSA (1987) pointed out some osteological similarities between pinguipedids and notothenioids; PIETSCH (1989) placed the family within the trachinoids. Rosa (1993) supported the monophyly of the family, based on the following putative apomorphies: a projection on the intercalar bone; the presence of a unique oblique crest on the hyomandibula, and a long lateral projection on the sphenotic.

The family Pinguipedidae, as shown by RoSA (1987), is represented in South America by three endemic genera (Pinguipes, Prolatilus and Pseudopercis) and a single species of Parapercis. Pinguipes includes two species, one distributed from Rio de Janeiro, Brazil to Argentina (P. brasilianus), the other along the coast of Peru and Chile (P. chilensis); Prolatilus includes only one species ( $P$. jugularis) which occurs on the coast of Peru and Chile; Pseudopercis includes two species, one restricted to Southern Brazil (P. numida), the other found from Rio de Janeiro, Brazil, to Argentina (P. semifasciata). Parapercis dockinski is only known from the Juan Fernandez Island, Chile.

1) Departamento de Sistemática e Ecologia, Universidade Federal da Paraiba. 58059-900 João Pessoa, Paraiba, Brazil. 
South American pinguipedids reach an adult size of at least $30 \mathrm{~cm}$, some reaching $1 \mathrm{~m}$. Most of them are commercially exploited (MANN 1954; LOPEZ 1963; BELLISIO et al. 1979). Despite their commercial value, these fishes are poorly represented in collections. Virtually nothing has been published on their taxonomy, and most of the literature on the group consists of citations in classifications (e.g. JORDAN 1923; SCHULTZ 1960) and catalogs or systematic lists (GÜNTHER 1860; IHERING 1897; EVERMANN \& KENDALL 1907; RIBEIRO 1915, 1918; RINGUELET \& RINGUELET 1960; MENNI et al. 1984). ROUX (1973) and FIGUEIREDO (1981) pointed out the need for revisionary studies in this group.

In this paper, a family definition, a discussion of the taxonomic status of the nominal South American genera and species of the family Pinguipedidae are included; the six valid species are diagnosed and redescribed. A more detailed osteological and phy logenetic study of the Pinguipedidae will be treated in a separate paper.

\section{MATERIAL AND METHODS}

Measurements were made with dial calipers, to the nearest $0.1 \mathrm{~mm}$; ranges of proportional measurements in the species descriptions are given as percent standard length, and are followed in parantheses by the sample mean and proportional measurements of the type, when available. Counts and measurements follow the methods of HUBBS \& LAGLER (1964). Osteological characters were observed from radiographs, dissected or cleared and stained specimens (TAYLOR \& VAN DYKE 1985); osteological nomenclature follows PIETSCH (1989). Institutional abbreviations follow LEVITON et al. (1985); (UFPB) Universidade Federal da Paraíba, João Pessoa, Brazil and (ZVC) Universidad de Humanidades y Ciencias, Montevideo, Uruguay are added. Photographs were taken by the authors, except were other credits are given.

\section{TAXONOMIC BACKGROUND}

The first descriptions of pinguipedid fishes are found in the third volume of the Histoire Naturelle des Poissons (CUviER in CUVIER \& VAlenciennes 1829). In that publication, there are accounts on the external morphology and illustrations of Pinguipes brasilianus and Percis semifasciata (= Pseudopercis semifasciata). Both species were placed in Cuvier and Valenciennes' Percoides. A previous citation ("Les Pinguipes") found in the Régne Animal (Cuvier 1829), has been treated as a vernacular name (ESCHMEYER \& BAILEY 1990; see Remarks under Pinguipes herein).

Posteriorly, Valenciennes (in CUVIER \& VALENCIENNES 1833) described Pinguipes chilensis and Latilus jugularis (= Prolatilus jugularis) and indicated that the latter species externally resembled Pinguipes; however, the two species were placed in different taxonomic groups: Latilus jugularis in the Scienoides, Pinguipes chilensis in the Percoides. The aforementioned genera were first treated as part of a single taxon by GÜNTHER (1860). 
GÜNTHER (1860) established the family Trachinidae, consisting of four groups (see PIETSCH 1989). The group Trachinina included 10 genera; one of them, Percis, contained species presently placed in Parapercis and Pseudopercis. Another group, Pinguipedina, from which the name Pinguipedidae stems, included Pinguipes and Latilus (Prolatilus in part). Shortly after its publication, Günther's scheme was modified by GüNTHER (1861) and GILL $(1872,1893)$, but with regards to pinguipedids, little was changed.

BOULENGER (1901), after rejecting both Günther's and Gill's proposals “on osteological grounds", removed Parapercis from the Trachinina, placing it (and 14 other genera) under the Nototheniidae. He also restricted the Pinguipedina (which he called family Pinguipedidae) to Pinguipes and placed Latilus in the Pseudochromidae. Twelve years later, Boulenger's proposal for pinguipedids was modified by REGAN (1913), who returned Parapercis to that group and added another genus, Neopercis (=Parapercis) to it. Regan's (1913) scheme remained virtually unchanged until the paper by JORDAN (1917), who erroneously synonymyzed Pinguipes with Mugiloides; later, he (JORDAN 1923) erected the family Mugiloididae to replace Pinguipedidae, including in it the genera Mugiloides, Myxonum, Pseudopercis and Pinguipes. Parapercis was placed in a separate family, Parapercidae. Subsequent authors followed Jordan's classification, and the name Mugiloididae almost completely replaced Pinguipedidae in the literature.

RosA \& RosA (1987) resurrected from synonym the Pinguipedidae, which has been adopted in subsequent publications (PIETSCH 1990; PIETSCH \& ZABETIAN 1991; ESCHMEYER \& BAILEY 1990; NELSON 1994).

\section{FAMILY SYNOMYMY}

The following synonymy includes sensu strictus synonyms, as well as other suprageneric taxa in which pinguipedid fishes have been placed at various times. Each synonym is followed by the first citation of a pinguipedid genus in it, and by the subordinate taxa listed by the respective author.

The taxa Trachinoidei and Percoidei, despite not having family-name ending, were treated as such by BLEEKER (1859) and for this reason are included in the synonymy.

\section{Pinguipedidae Günther, 1860}

Percidae (in part); Jenyns, 1842: 20, Pinguipes fasciatus and P. brasiliamus.

Sciaenidae (in part); Jenyns, 1842: 51, Latilus jugularis.

Trachinoidei (in part); Bleeker, 1859: XXIV, Percis and Pinguipes.

Percoidei (in part); Bleeker, 1859: 110, Percis.

Trachinidae (in part); Günther, 1860: 225, Parapercis, Pinguipes and Latilus.

Trachinina (in part); Günther, 1860: 232, Parapercis.

Pinguipedina (in part); Günther, 1860: 251, Pinguipes and Latilus.

Latilidae (in part); Gill, 1881: 162, Prolatilus and Pinguipes.

Malacanthidae; Berg, 1895: 61, Pinguipes somnambula.

Nototheniidae (in part); Boulenger, 1901: 265, Parapercis. 
Pinguipedidae; Boulenger, 1901: 271, Pinguipes.

Parapercidae Regan, 1909: 85, no genera mentioned.

Mugiloididae Jordan, 1923: 229, Mugiloides, Pinguipes and Pseudopercis.

Parapercichthyidae Whitley and Phillips, 1939: 235, Parapercichthys.

Branchiostegidae (in part). Fowler, 1951b: 306, Prolatilus jugularis.

Mugilidae (sic); Carvalho, 1956: 201, Neopercis atlanticus meridionalis.

\section{Type genus: Pinguipes}

Diagnosis. Hyomandibula with oblique crest (GosLINE 1968); intercalar with sharp, posteriorly directed process; sphenotic with elongate, anteriorly directed process (only the first character could be checked for Kochichthys).

Definition. Demersal trachinoid fishes which occur primarily in tropical and subtropical waters, mainly at shallow depths. Body elongate but robust, nearly cylindrical behind the head, becoming progressively more compressed towards the caudal peduncle; dorsal profile slightly convex, ventral nearly flat. Head conical in profile (markedly conical only in Pinguipes), mouth terminal, jaws equal or lower jaw slightly longer (in a few species of Parapercis); upper lip fleshy (except in Prolatilus and Kochichthys); eyes near dorsal profile of head, two pairs of nostrils, the anterior with membranous flap; dorsal fin elongate, III-VII+19-29; its origin in a vertical line with base of pectoral fin, its end immediately before caudal peduncle. Anal fin elongate, I-II+16-26; its origin between 6th and l0th dorsal fin rays, its end immediately before caudal peduncle. Caudal fin truncate or slightly forked (in some species of Parapercis), with 13-15 principal rays; upper half of caudal fin base with black spot; pelvic fin I+5, its origin below or slightly before the pectoral fins base, its end not reaching or barely reaching anal fin origin. Pectoral fins with 15-21 rays, its origin in a vertical line with origin of dorsal fin, its end slightly beyond anal fin origin. Snout, interorbital and gular regions naked (except in Prolatilus and Kochichthys), rest of the head covered with cycloid and ctenoid scales. Body covered with ctenoid scales, except for minute cycloid scales on pectoral-fin base and proximal half of its rays, and on base of caudal-fin rays. Lateral line on middle of body, following its dorsal profile, with 56-81 scales. Premaxillae and dentaries with one outer row of canine-like teeth, followed by several rows of villiform teeth. Teeth present on vomer (except in Prolatilus) and palatines (except in Prolatilus and some species of Parapercis). Six acinaciform branchiostegal rays; branchial membranes united and free from isthmus; 9-26 gill rakers; 9-18 abdominal vertebrae, 18-23 caudal.

\section{Key to the genera of Pinguipedidae}

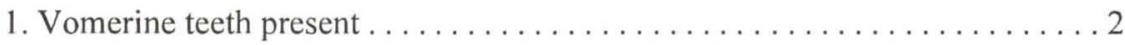

- Vomerine teeth absent ............................ Prolatilus

2. Snout scaleless; five to seven spines in dorsal fin ................ 3

- Snout scaled; three spines in dorsal fin ................. Kochichthys

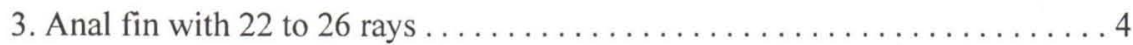

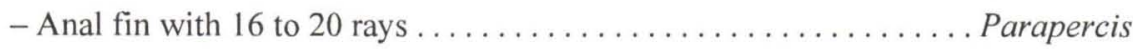


4. Dentaries with an outer row of 20-29 teeth; upper lip (measured from its anteriormost tip to premaxillary symphysis) fleshy (6.2-11.9 in head length) $\ldots \ldots \ldots \ldots \ldots \ldots \ldots \ldots \ldots \ldots \ldots \ldots \ldots \ldots \ldots \ldots \ldots \ldots \ldots \ldots \ldots$ Pinguipes

- Dentaries with an outer row of 30 to 36 teeth; upper lip slightly fleshy ....... Pseudopercis

\section{Pinguipes Cuvier, 1829}

Pinguipes Cuvier 1829, in Cuvier \& Valenciennes, Histoire Naturelle des Poissons, vol. 3: 277, plate 63 (type species Pinguipes brasilianus, by monotypy). - Jenyns, 1842: 21. - Guichenot, 1848: 164. - Bart, 1852: 169. - Günther, 1860: 251. - Günther, 1880: 466. - Gill, 1881: 164. - Boulenger, 1901: 271. - Ribeiro, 1903: 40. - Ribeiro, 1915: 11. - Jordan, 1917: 127, - Jordan, 1923: 229, -Devincenzi, 1924: 255. - Giltay, 1933: 80. - Gregory, 1933: 357, 358, 363. - Pozzi \& Bordalé, 1935: 174. - Schneider, 1943: 111. -Fowler, 1951a: 294. - Ringuelet \& Aramburu, 1960: 35. Schultz, 1960: 267. - Cantwell, 1964: 243. - Norman, 1966: 360. - Roux, 1973: 153. - Menni et al., 1984: 50, 56, 179, 180. - Nelson, 1984: 343. - Randall, 1984: 41. - Menezes \& Figueiredo, 1985: 45. - Rosa \& Rosa, 1987. - Eschmeyer \& Bailey, 1990: 316. - Nelson, 1994: 398.

Mugiloides (non Lacépede, 1803); Jordan, 1917: 127. - Jordan, 1923: 229. - Hildebrand, 1946: 356. Norman, 1966: 361. - Figueiredo, 1981: 40. - Umaran, 1982: 58. - Randall, 1984: 41. - Nelson, 1984: 343 .

Remarks. The name "Pinguipes" appeared in the second edition of the Régne Animal (CUVIER 1829) and in the third volume of Histoire Naturelle des Poissons (Cuvier \& Valenciennes 1829). In the Régne Animal, it appeared as "Les Pinguipes" followed by the citation "Ping. brasilianus Cuv. Val.". Based on the dates of publication for the Régne Animal and the third volume of the Histoire Naturelle des Poissons given by Fowler (1907), BAILEY (1957) WHITEHEAD \& MYERS (1971) and ROSA \& ROSA (1987) granted priority to the Régne Animal, treating the short descriptive account under "Les Pinguipes" Cuv. Val. as a combined definition and indication of the names Pinguipes and the single included species, Ping. brasilianus Cuv. Val. (type species by monotypy). However, ESCHMEYER \& BAILEY (1990), treated "Les Pinguipes" as a vernacular name and considered the citation "Ping". insufficient to latinize Pinguipes. According to this interpretation, the authorship of the genus and type species should be treated as of Cuvier in CUVIER \& VALENCIENNES (1829).

Diagnosis. Upper lip thick and fleshy, notably at symphysis level; snout conical; 15 to 16 abdominal vertebrae; occipital crest moderately developed.

\section{Key to the species of Pinguipes}

1. Tongue narrow and pointed; sides of body with seven dark bars, and five intermediate narrower and lighter bars; distributed from Rio de Janeiro, Brazil, to Golfo Nuevo, Argentina . ................ brasilianus

- Tongue broad with rounded anterior margin, occupying most of floor of mouth cavity; sides of body with two longitudinal series of light-bluish spots; distributed from Tumbes, Peru to Magellanes, Chile ...........chilensis 


\section{Pinguipes brasilianus Cuvier}

Figs 1-4

Pinguipes brasilianus Cuvier 1829, in Cuvier \& Valenciennes: 277, plate 63 (original description, Brazil). - Jenyns, 1842: 20. -Guichenot, 1848: 165. - Günther, 1860: 251. - Gill, 1881: 164. -Ribeiro, 1903: 11. - Ribeiro, 1918: 146. - Giltay, 1933: 80. -Fowler, 1942: 177. -Fowler, 1951a: 28. - Thering, 1968: 483. -Roux, 1973: 153. - Figueiredo, 1981: 40. - Nonato, Amaral \& Figueiredo, 1983: 179. - Menni, Ringuelet \& Aramburu, 1984: 179. -Menezes \& Figueiredo, 1985: 45.

Pinguipes fasciatus Jenyns, 1842: 20, plate 5 (original description, Patagonia). Guichenot, 1848: 166. Günther, 1860: 252. - Berg, 1895: 61. - Berg, 1899: 173. - Ihering, 1897: 52, 54. - Ribeiro, 1903: 40. - Ribeiro, 1915: 13. - Ribeiro, 1918: 146. -Devicenzi, 1924: 225. - Pozzi \& Bordalé, 1935 174. - Devicenzi \& Legrand, 1940, plate 37. - Ringuelet \& Aramburu, 1960: 76. - Roux, 1973: 153. - Bellisio et al., 1979: 202. - Menni et al., 1984: 180. - Nakamura in Nakamura et al., 1986: 266, 267.

Neopercis atlanticus meridionalis Carvalho, 1956: 199 (original description, Cabo Frio, Brazil). Figueiredo, 1981: 39. designated.

Lectotype of Pinguipes brasilianus. MNHN 1715, coll. Delalande, herein

Type locality. Brazil.

Common names. Michole-quati (Brazil), chanchito, turco (Argentina).

Remarks. Pinguipes brasilianus was described in the the Histoire Naturelle des Poissons (Cuvier in Cuvier \& Valenciennes 1829). The description of its external morphology was subsequently supplemented with anatomical data (VALENCIENNES in CUVIER \& VALENCIENNES 1833).

JENYNS (1842) described P. fasciatus based on H.M.S. Beagle's material from Patagonia. He pointed out its striking similarity with $P$. brasilianus, but mentioned the following differences between the two species: body proportions, position of palatine teeth, position of pelvic fins, number of anal-fin rays, and deeper recess on the branchial membrane of $P$. fasciatus. RiBEIRo (1915) mentioned that $P$. brasilianus and $P$. fasciatus possibly represented the same species, and later (RIBEIRo 1918), synonymized the two species. We agree with the synonymy proposed by RIBEIRO (1918), as Jenyn's (1842) observations were either erroneous or represented intraspecific variation.

CARValHo (1950) recorded Neopercis sp. from Cabo Frio, Brazil. Subsequently, CARVALHO (1956) described Neopercis atlanticus meridionalis based on the same specimen. FigueIrEDo (1981) examined Carvalho's material and concluded that it represented a young specimen of $P$. brasilianus. Such identification was corroborated by our review of the original description and type material of Neopercis atlanticus meridionalis.

Material examined. BMNH 1917.17.14.51 (1), Coast of Patagonia (type of P. fasciatus); BMNH 90.2.25.15 (1), San Antonio, Eastern Patagonia; MACN 5017 (2), Puerto Quequén, Argentina; MACN 2852 (1), Mar del Plata, Argentina; MACN 2070 (1), San Antonio, Punta Vilarino, Argentina; MACN 2506 (1), Golfo Nuevo, Argentina; MCZ 12870 (5), Puerto San Antonio, Argentina; MCZ 12871 (1), Puerto San Antonio, Argentina; MCZ 25264 (1), Puerto San Antonio, Argentina; MCZ 12878 (1), Maldonado, Uruguay; MCZ 12877 (1), Rio de Janeiro, Brazil; MNHN 
1715 (1), Brazil (lectotype of Pinguipes brasilianus, here designated); MNHN 5495 (1), Brazil; MNRJ 1654 (1), Rio de Janeiro, Brazil; MZUSP 7723 (1), Ubatuba, São Paulo, Brazil; MZUSP 2599 (1), Ilha dos Búzios, São Paulo, Brazil; MZUSP 19214 (1), 2330'S, 42²7'W; MZUSP 19215 (1), ibid; MZUSP 19216 (1), ibid; MZUSP 19217 (1); MZUSP 19218 (1), ibid; MZUSP 19219 (1), ibid; MZUSP 19220 (1), ibid; MZUSP 19221 (1), ibid; MZUSP 19222 (1), ibid; MZUSP 19226 (1), 23ํ'16'S, $41^{\circ} 56^{\prime} \mathrm{W}$; USNM 83241 (1), Rio de Janeiro, Brazil; USNM 86695 (1), Islas Lobos, Uruguay.
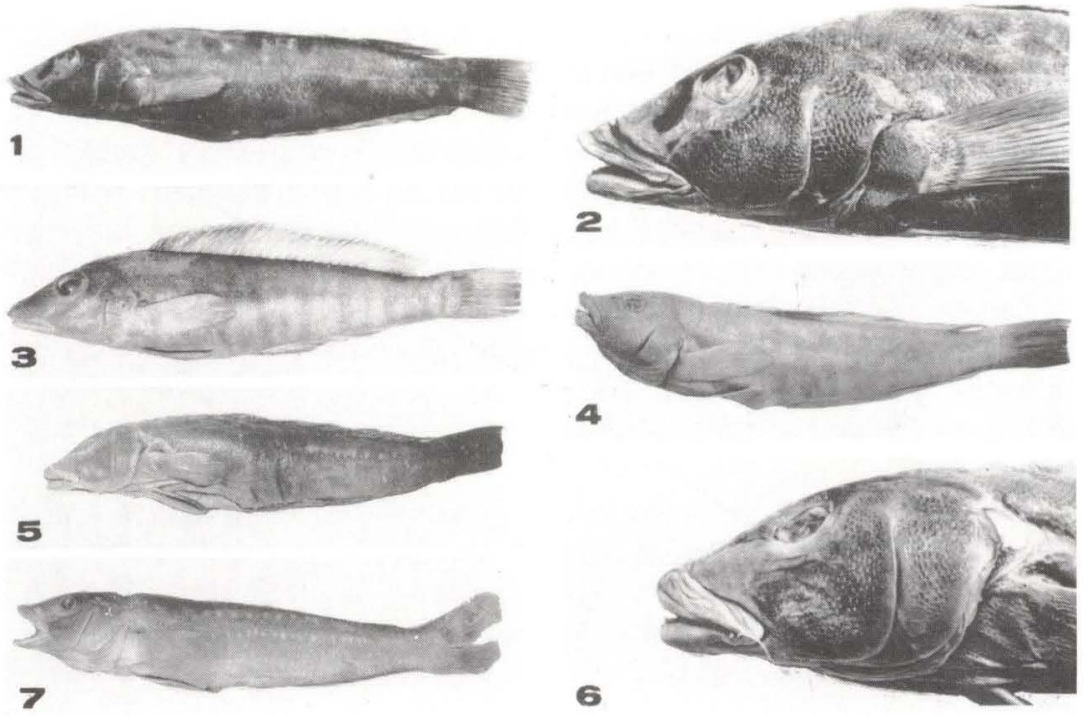

Figs 1-7. (1) Pinguipes brasilianus, left lateral view of lectotype, 295.2mm SL (MNNH 1715); (2) Pinguipes brasilianus (MNNH 1715), lateral view of head; (3) Pinguipes brasilianus, $206 \mathrm{~mm}$ SL (MZUSP 7723), left lateral view; (4) left lateral view, type of Pinguipes fasciatus, $262 \mathrm{~mm}$ SL (BMNH 1917.17.14.51); (5) Pinguipes chilensis, left lateral view of lectotype, $295.8 \mathrm{~mm} \mathrm{SL}$ (MNHN 4902); (6) Pinguipes chilensis, lectotype (MNHN 4902), lateral view of head; (7) Pinguipes chilensis, $227.3 \mathrm{~mm}$ SL (USNM 11490), left lateral view.

Diagnosis and description. D vi-vii, 24-27; vomer with an anterior row of 4-6 and a posterior row of 3-4 teeth; sides of body with seven dark bars and five intermediate lighter and narrower bars. Total length $91.3-396 \mathrm{~mm}(262,346)$; standard length $75.4-338.9 \mathrm{~mm}(220,259)$; head length $23.3-37.1(28.7,31.4)$; snout length 9.2-14.5 $(11.8,13.4)$; horizontal length of orbit 3.3-7.2 $(6.2,5.9)$; bony interorbital width 2.1-7.6 (5.0, 7.6); predorsal length 21.2-32.2 (28.4). Upper jaw with an outer row of 33-35 conical teeth, backed by 3-5 rows of villiform teeth; lower jaw with outer row of 24-28 conical teeth, backed by 4-7 rows of villiform teeth; posterior margin of preopercle sinuose; posterior margin of opercle entire, with two spines in dorsal angle, covered by skin; $15-19$ gill rakers on first branchial arch; pharyngeal teeth conical, numerous. Dorsal fin long, its basal length 50.1-70.4 $(61.5,70.4)$; dorsal-fin soft rays slightly longer than last spine; origin of dorsal fin 
in same vertical line as base of pectoral fin. Anal fin long, its basal length 36.6-51.6 $(40.7,46.7)$, its origin in vertical line between 6 th and 8th dorsal-fin rays; anal-fin spines flexible, first spine reduced. Caudal peduncle depth 8.7-12.0 (9.8, 12.0); caudal fin with truncate posterior margin and 17 principal rays. Origin of pelvic fin slightly anterior to or immediately below base of pectoral fin, its posterior margin not reaching anal fin. Origin of pectoral fin in same vertical as origin of dorsal fin, its posterior margin rounded, not reaching or slightly beyond vertical through origin of anal fin. Snout, interorbital and gular regions naked, other portions of head scaly. Pectoral and caudal fins with minute scales at their bases, other fins naked.

Colour in alcohol. Head light-brown dorsally, ventrally pale; body lightbrown dorsally, from base of dorsal fin to lateral line, ventrally pale. Seven dark-brown bars and five intermediate light-brown bars on side of body, from base of dorsal fin to approximately 10 th row of scales above ventral profile. Anteriormost bar at level of dorsal fin origin, posterior bar on caudal peduncle. Dorsal fin light-brown with two longitudinal black lines, one along its base and other above mid fin height. Three anteriormost dorsal-fin spines black. Anal fin light-brown with dark-brown line along its margin. Caudal fin light-brown at base and darkbrown at distal third, its upper lobe with conspicuous black oval spot. Colour pattern of juvenile specimens similar to that of adults, with more conspicuous bars and caudal spot. The colour pattern of fresh specimens has been described in detail by RIBEIRO (1903).

Miscellaneous data. According to Roux (1973), Pinguipes brasilianus reaches up to $70 \mathrm{~cm}$ in total length. BELLISIO et al. (1979) indicated that this species has little commercial value in Argentina, due to its small size. Menezes \& FIGUEIREDO (1985) mentioned that the species has no commercial importance in Brazil and occurs between 60 and $150 \mathrm{~m}$ of depth. All specimens examined in this study were captured within this depth range.

Geographic distribution. Rio de Janeiro, Brazil, to Golfo Nuevo, Argentina.

\section{Pinguipes chilensis Valenciennes, 1833}

\section{Figs 5-7}

Pinguipes chilensis Valenciennes 1833, in: Cuvier \& Valenciennes: 457 (original description, coast of Valparaiso, Chile). - Jenyns, 1842: 22. - Guichenot, 1848: 152. - Günther, 1860: 252. - Quijada, 1912: 77. - Evermann \& Radcliffe, 1917: 112. - Schneider, 1943: 111. - Fowler, 1944: 122. Fowler, 1945a: 237. - Bahamonde, 1950: 13. - Fowler, 1951b: 294.

Esox chilensis (non Molina, 1782: 222). - Guichenot, 1848: 165. Günther, 1860: 252. - Evermann \& Radcliffe, 1917: 112. - Fowler, 1944: 122. - Hildebrand, 1946: 356. -Mann, 1954: 268. -Koepcke, 1963: 330.

Mugiloides chilensis (non Lacépède, 1803: 50). - Jordan, 1917: 62, 127. - Hildebrand, 1946: 356. Mann, 1954: 62, 84, 268. - Koepcke, 1963: 330. - Bahamonde \& Pequeño, 1975: 14. - Navarro \& Pequeño, 1979: 267. - Moreno \& Zamorano, 1980: 245.

Pseudopercis chilensis. Ribeiro, 1903: 41.

Type locality. Valparaiso, Chile.

Lectotype of Pinguipes chilensis. MNHN 4902, coll. Claude Gay, herein designated. 
Common names. Rollizo (Chile and Peru), bacalao, canguro, camote, camotillo (Peru).

Remarks. The description of Pinguipes chilensis was based on manuscript notes and three specimens collected by Claude Gay. GUICHENOT (1848) redescribed the species and, without justification, synonymized it with Esox chilensis Molina, 1782. JORDAN (1917) treated Mugiloides chilensis (=Mugil chilensis Molina, 1782) as the valid name of the species. The study of the original descriptions of Esox chilensis and Mugil chilensis revealed that these species are distinct from Pinguipes chilensis, and that the latter is a valid genus and species (ROSA \& ROSA 1987).

Material examined. BMNH 48.6.14.7 (1), South America; MCZ 12878 (1), Talcahuano, Chile; MCZ 12873 (1), ibid; MCZ 12874 (1), ibid; MNHN 4902 (lectotype of Pinguipes chilensis, here designated), Valparaiso, Chile; MNHN 1812 (2 paralectotypes of $P$. chilensis, here designated), Chile; MNHN 07363 (1), Coast of Chile; IZUC (1), uncatalogued, Bahía de Concepción, Chile; USNM 128052 (1), Isla Pachamac, Chile.

Diagnosis and description. D vi, 25-29; body with two series of light-blue spots along lateral line; supraoccipital crest low, only on posterior half of bone; parietal crest absent; Total length 99.8-501 mm (307, 325); standard length 96.9$430.4 \mathrm{~mm}(277,296)$; head length 27.5-41.1 (30.1, 37.4); snout length 9.8-18.8 $(12.6,16.0)$; horizontal diameter of orbit 3.3-11.8 $(4.3,5.9)$; bony interorbital width 3.8-10.7 (5.9, 8.6); predorsal length 17.4-26.0 (18.2). Upper jaw with external row of 25-29 conical teeth, backed by several rows of villiform teeth. Lower jaw with external row of 20-30 conical teeth, backed by several rows of villiform teeth. Vomer with an anterior row of 6-7 teeth and a posterior row of 4-5 conical teeth. Posterior margin of preopercle entire; posterior margin of opercle entire, with two spines on dorsal angle, covered by skin. Superior spine blunt; inferior spine pointed, larger than in P. brasilianus. First gill arch with 16-19 gill rakers. Dorsal fin long, its basal length $36.0-51.3(61.4,76.1)$; dorsal-fin rays slightly longer than last spine. Origin of dorsal fin in same vertical as base of pectoral fin. Anal fin long, its basal length 30.1-53.1 (40.6,51.3), its origin in vertical line between 7 th and 9 th dorsal-fin rays; anal-fin spines flexible and reduced. Caudal fin with truncate margin and 17 principal rays. Position of pectoral and pelvic fins same as in $P$. brasilianus. Snout, interorbital and gular regions naked; other parts of head scaly. Pectoral and caudal fins with minute scales at their bases; other fins naked.

Colour in alcohol. Head and body brown or grey, dorsal half slighthly darker; two series of whitish spots close to lateral line. Dorsal, pelvic, anal and caudal fins greyish-brown; dark semicircular area at base of pectoral fins. Dorsal lobe of caudal fin with dark oval spot, conspicuous in juvenile specimens. The colour pattern of fresh specimens is given in the original description (CUVIER \& VALENCIENNES 1833) and in MANN (1954).

Miscellaneous data. Pinguipes chilensis inhabits muddy bottoms (MANN 1954) or sandy and rocky bottoms (SCHNEIDER 1943). According to SCHNEIDER (1943), this species reaches depths up to $100 \mathrm{~m}$, is abundant during fall and winter in Concepción and Arauco, and spawns during spring.

Geographic distribution. From Tumbes, Peru to Magellanes, Chile. 


\section{Parapercis Bleeker, 1863}

Parapercis Bleeker, 1863: 236. (Type species Sciaena cylindrica Bloch, 1797).

Remarks. A single species of Parapercis is presently known for the coast of South America. A synonymy and diagnosis for this genus are given by CANTWELL (1964).

\section{Parapercis dockinski McCosker}

Parapercis dockinski McCosker, 1971: 682, figs 1-3 (original description and illustration, Juan Fernandez Islands, Chile). -Bahamonde \& Pequeño, 1975: 14. - Gomon, 1980: 989.

Holotype. SIO 65-637.

Material examined. MCZ 52791 (20), Coast of Chile, "Anton Bruun" expedition, Station number 35; SIO65-647 (6), Coast of Chile, Juan Fernandez Islands ( $\left.33^{\circ} 38^{\prime} \mathrm{S}, 78^{\circ} 45.8^{\prime} \mathrm{W}\right)$.

Diagnosis and description. D v, 21-23; 10 abdominal vertebrae; four anterior canine teeth in external tooth row of each dentary, separated from three lateral canine teeth by edentulous space; interopercle and subopercle with sharp process on posterior margins. Total length $98.6-206 \mathrm{~mm}$ (148.5); standard length $84.7-172 \mathrm{~mm}$ (140.7); head length 27.2-30.0 (25.6); snout length 7.9-11.4 (9.8); horizontal length of orbit 7.1-8.3 (7.8); bony interorbital width 1.5-2.6 (1.8); predorsal length 28.231.0 (29.6). Upper jaw with external row of 8-9 canine teeth and $28-29$ small conical teeth, backed by eight rows of villiform teeth; lower jaw with eight canine teeth, followed by group of smaller teeth and posteriorly by 26-28 conical teeth. Vomer with external row of 9-10 conical teeth (MCCOSKER 1971 illustrated 12 teeth) and ca. 14 smaller conical teeth, irregularly distributed. Posterior margin of preopercle slightly crenulated, posterior margin of opercle entire, with one spine covered by skin on dorsal angle. First gill arch with 12-16 gill rakers. Dorsal fin long, its basal length 47.8-69.3 (62.5). Anal fin long, its basal lentgh 34.6-49.1 (47.5), its origin in vertical line between 6th and 8th dorsal-fin rays; anal-fin spines flexible, first one reduced. Caudal peduncle depth 8.2-9.6 (8.8); caudal fin with truncate margin and 17 pricipal rays. Snout, interorbital and gular regions naked; other parts of head scaly. Pectoral and caudal fins with minute scales at their bases; other fins naked.

Colour in alcohol. Head and body light-brown. Five paired dark bars on sides of body, from origin of dorsal fin to caudal peduncle; first pair preceeded by incomplete bar, from dorsal profile to lateral line level. A dark-brown oval spot behind eye. Base of pectoral fin brown; pelvic fins with dark-brown stripe along internal rays. Base of caudal fin with dark vertical bar, posteriorly followed by five or six light bars; dorsal lobe of caudal fin with dark oval spot. MCCOSKER (1971) remarked that specimens taken in shallow water showed relatively darker colour pattern than those from deeper waters.

Miscellaneous data. Parapercis dockinski is a small-sized species, which inhabits depths of about 155 m (MCCOSKER 1971).

Geographic distribution. Parapercis dockinski is known only from Juan Fernandez Island, Chile. 


\section{Prolatilus Gill, 1865}

Prolatilus Gill, 1865: 67 (type species Latilus jugularis Valenciennes 1833, in Cuvier \& Valenciennes, by monotypy).-Gill, 1881: 164.-Fowler, 1951b: 306. - Schultz, 1960: 267. - Navarro \& Pequeño, 1979: 267. - Eschmeyer \& Bailey, 1990: 333. - Nelson, 1994: 398.

Porteridia Fowler, 1945b: 25. - Fowler, 1951b: 294. - McCosker, 1971: 682.

Remarks. SCHULTZ (1960) was the first author to include Prolatilus in the family Mugiloididae; traditionally that genus was referred to the families Branchiostegidae and Malacanthidae. Valenciennes (in CUVIER \& VALENCIENNES 1833) pointed out the morphological similarity between Latilus jugularis and Pinguipes, but placed them in separate groups. GÜNTHER (1860) included the known species of Latilus and Pinguipes in the same suprageneric category. GILL (1881) remarked that Prolatilus and Pinguipes apparently had a close relationship. NELSON (1984) included Prolatilus pinguipes, Mugiloides and Parapercis in the Mugiloididae.

Description. D iv, 27-29; vomer and palatines edentulous; head scaly, except on gular region and anterior portion of lower jaw; tongue with numerous denticles, all over its surface in adults, or along its anterior margin in young; pelvic fins insertion more anterior than in other pinguipedids.

\section{Prolatilus jugularis (Valenciennes, 1833) \\ Figs 8 -9}

Latilus jugularis Valenciennes 1833, in Cuvier \& Valenciennes: 500, plate 279 (original description, Valparaiso, Chile). Jenyns, 1842: 51; Guichenot, 1848: 203; Günther, 1860: 253; Quijada, 1912: 77; Schneider, 1943: 112; Fowler, 1944: 121; Fowler, 1945a: 246; Mann, 1954: 246.

Prolatilus jugularis. Gill, 1865: 67. Gill, 1881: 164. - Fowler, 1951b: 306. - Mann, 1954: 62, 226. Fischer, 1958: 3. - Buen, 1959: 99. - Kasulovic \& Astete, 1966: 38. - Navarro \& Pequeño, 1979: 267. - Nakamura 1986 in Nakamura et al: 204.

Parapercis chilensis Norman, 1937: 62, fig. 28 (original description, Isla Mocha, Chile). Schneider, 1943: 112. - McCosker, 1971. - Navarro \& Pequeño, 1979: 267.

Porteridia chilensis. Fowler, 1945b: 25 (new combination).

Type locality. Valparaiso, Chile.

Lectotype of Prolatilus jugularis. MNHN 8156, herein designated, coll. Claude Gay.

Paralectotypes of Prolatilus jugularis. MNHN 7647 (2 specimens), Valparaiso, coll. Claude Gay, herein designated

Common names. Blanquillo, peje blanco, cabrilla.

Remarks. NORMAN (1937) described Parapercis chilensis and FowLER (1945b) subsequently established the genus Porteridia for that species. MCCOSKER (1971) synonymized Parapercis chilensis with Prolatilus jugularis. Our study of the type material and the original descriptions of these species confirmed the synonymy proposed by MCCOSKER (1971).

Material examined. ANSP 70320 (1), Isla Mocha, Chile; ANSP 70321 (1), ibid; BMNH 1936.8.26.441-2 (1), 38² $28^{\prime} \mathrm{S}, 7^{\circ} 41^{\prime}$ W; BMNH 1936.8.26.440 (1), ibid (type of Parapercis chilensis); MCZ 25226 (1), Valparaiso, Chile; MCZ 12858 (2), ibid; MNHN 8156 (lectotype of Prolatilus jugularis, here designated), Valpa- 
raiso, Chile; MNHN 7646 (2 paralectotypes of $P$. jugularis, here designated), ibid; MNHN 7647 (2), ibid; MZUSP 19230 (1), San Antonio, Chile; MZUSP 19231 (1), ibid; MZUSP 19232 (1), USNM 21375 (3), near Corral, Chile, 39²' 'S, 73⒉' W; USNM 083034 (1), Peru; USNM 176470 (2), Bahía Tictoc, Chile; USNM 176469 (1), Bahía Chiloé, Chile; USNM 083097 (1), Valparaiso, Chile; USNM 176556 (1), Bahía Caldera, Chile; USNM 176428 (2), Coquimbo, Chile; USNM 211453 (4),

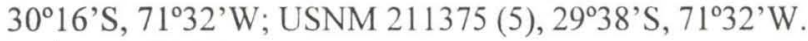
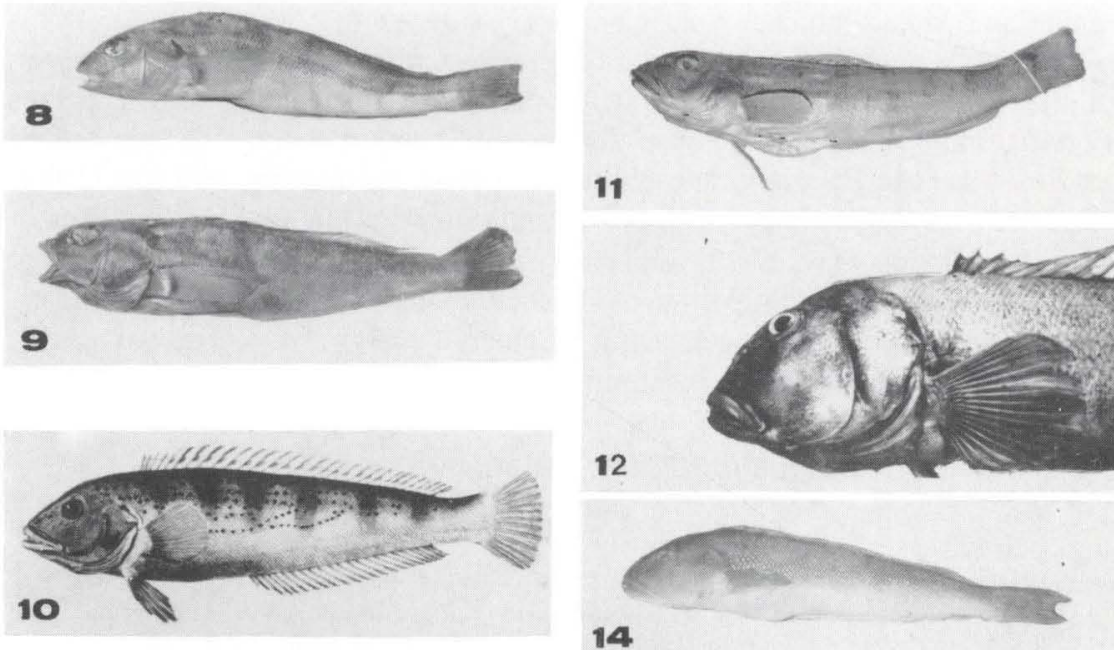

12

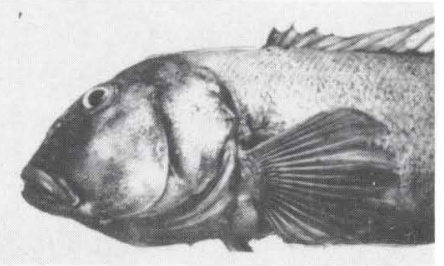

14

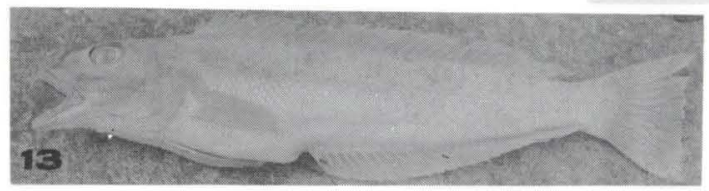

Figs 8-14. (8) Prolatilus jugularis, 221.9mm SL (MCZ 12858), left lateral view; (9) type of Parapercis chilensis, 229.5mm SL (BMNH 1936.8.26.440), Inverted right lateral view; (10) Pseudopercis semifasciata, original illustration of Percis semifasciata, from Cuvier \& Valenciennes, 1829, pl. 62; (11) Pseudopercis semifasciata, 228mm SL (MZUSP 19223), left lateral view; (12) type of Pinguipes somnambula, inverted right lateral view, $87.2 \mathrm{~cm} \mathrm{SL}, 18.6 \mathrm{~cm}$ head length (MACN 6622), photograph by H.P. Castello; (13) Pseudopercis numida, left lateral view of holotype, 292mm SL (MNRJ 2237); (14) Pseudopercis numida, 385mm SL (UFPB 1745), left lateral view.

Diagnosis and description. D iv, 27-29; dorsal profile of head and body convex, ventral profile nearly straight; posterior margin of maxilla reaching vertical line through anterior margin of orbit. Upper jaw with external row of 25-28 conical teeth, backed by several rows of villiform teeth; lower jaw with external row of 29-33 conical teeth, backed by several rows of villiform teeth. No teeth on vomer and palatines. Posterior margin of preopercle entire, with three spines on dorsal angle. Total length $61.2-307 \mathrm{~mm}(201,156)$; standard length $52.0-268 \mathrm{~mm}(177$, $133)$; head length 26.9-36.0 (31.6, 29.9); snout length 8.3-12.9 (10.9, 8.3); horizon- 
tal length of orbit 4.8-10.6 (7.6, 9.6); bony interorbital width 2.0-5.9 (4.2, 2.8); predorsal length 28.42-34.3 (32.3). First gill arch with 13-17 gill rakers; pharyngeal teeth conical, small and numerous. Dorsal fin long, its basal length 51.7-67.7 (61.9, 61.7); dorsal- fin rays slightly longer than last spine. Origin of dorsal fin in same vertical as base of pectoral fin. Anal fin basal length 35.5-44.6 (38.2, 38.9), its origin in vertical line between 8 th and 10 th dorsal-fin rays. Caudal peduncle width 7.1-10.8 $(8.8,8.0)$; caudal fin with truncate posterior margin and 17 principal rays.

Head scaly except on gular region and anterior portion of lower jaw. Pectoral, pelvic and caudal fins with minute scales at their bases; other fins naked.

Colour in alcohol. Head and body dark-brown dorsally, light-brown on sides of body below lateral line, and light-yellow ventrally. Dorsal fin translucent with brown pigment along its base and margin; pectoral fins translucent, with conspicuous semicircular dark spot at base of rays; pelvic fins dark at distal margins; anal fin translucent with brown pigment along its margin; caudal fin brown, darker on distal margin. One specimen showed nine dark bars, the first at level of pectoral fin, the last on caudal peduncle. Colour of fresh specimens reported as whitish- grey on body, with brown tranverse bars (MANN 1954), or silvery with reddish tones on head (BUEN 1959).

Miscellaneous data. Prolatilus jugularis reaches ca. $40 \mathrm{~cm}$ in length; inhabits rocky and sandy bottoms and feeds on crustaceans, polichates and small fish. It is considered as a good quality fish and is commercially exploited (MANN 1954).

Geographic distribution. This species is known from Huacho, Peru ( $\left.11^{\circ} 11^{\prime} \mathrm{S}\right)$, to Chiloé, Chile, $43^{\circ} 43^{\prime} \mathrm{S}, 72^{\circ} 50^{\prime} \mathrm{W}$.

\section{Pseudopercis Ribeiro, 1903}

Pseudopercis Ribeiro, 1903: 41 (original description; type species Pseudopercis mumida by monotypy). Ribeiro, 1915: 9. Schultz, 1960: 267. - Figueiredo: 1981: 40. - Eschmeyer \& Bailey, 1990: 341.

Pinguipes (in part). Ribeiro, 1903: 41.

Prolatilis [sic] (non Gill, 1865). Cantwell, 1964: 243.

Mugiloides (non Lacépède, 1803). Norman 1966: 361. - Roux, 1973: 153.

Remarks. RIBEIRo (1903) described Pseudopercis in the family Malacanthidae, and subsequently, JORDAN (1923) placed it in the family Mugiloididae. CANTWELl (1964) treated Pseudopercis as a synonym of Prolatilus, and NoRMAN (1966) as a synonym of Mugiloides. Figueiredo (1981) pointed out that Pseudopercis is a valid genus, and not a synonym of Prolatilus. These latter genera differ in several aspects, such as the dentition on vomer and palatines and scales. The synonymy of Pseudopercis and Mugiloides also must be rejected because the latter genus does not belong to the Pinguipedidade (see ROSA \& ROSA 1987).

Diagnosis. Head and body comparatively more robust than in other pinguipedids; 17-18 abdominal vertebrae; dentaries with external row of 30-36 conical teeth; supraoccipital and parietal crests well developed on cranium. 


\section{Key to the species of Pseudopercis}

1. Dorsal fin iv-v+24-27; tongue short, lacking denticles; premaxillae with external row of $38-40$ teeth . . . . . . . . . . . . . . . . . . . semifasciata

- Dorsal fin vii+26-28; tongue with denticles; premaxillae with external row of $32-35$ teeth . . . . . . . . . . . . . . . . . . . . . . . . . . . .

\section{Pseudopercis semifasciata (Cuvier, 1829)}

Figs $10-12$

Percis semifasciata Cuvier 1829, in Cuvier \& Valenciennes, 1829: 276, plate 62 (description, unknown locality). Günther, 1860: 242. - Berg, 1899: 172. - Cantwell, 1964: 245.

Pinguipes somnambula Berg, 1895: 61 (original description, Mar del Plata, Argentina). Berg, 1899: 173. - Pozzi \& Bordalé, 1935: 174. - Ringuelet \& Aramburu, 1960: 76. - Bellisio et al., 1979: 202. -

Figueiredo, 1981: 40. - Menni et al., 1984: 180. - Nakamura 1986, in Nakamura et al.: 269.

Pinguipes semifasciatus. Berg, 1899: 172. Pozzi \& Bordalé, 1935: 174. - Menni et al., 1984: 179, 318.

Pseudopercis somnambula. Ribeiro, 1903: 41. Menni et al., 1984: 180.

Mugiloides somnambula; Roux, 1973: 153.

Pseudopercis semifasciata; Figueiredo, 1981: 40.

Pseudopercis semifasciatus; Nakamura in Nakamura et al., 1986: 269.

Common names. Namorado (Brazil), salmon de mar (Argentina).

Remarks. CUVIER (1829, Régne Animal) cited the name $P$. semifasciata without further account, referring it to the third volume of Histoire Naturelle des Poissons (CUVIER \& VALENCIENNES 1829); the latter publication is considered as the source of the species description. Percis semifasciata was described and illustrated from one specimen of unknown origin. BERG (1895) described Pinguipes somnambula from Argentina, and posteriorly BERG (1899) used the new combination Pinguipes semifasciatus for Percis semifasciata, and remarked that this taxon had several characters in common with Pinguipes somnambula, and possibly could represent the same species. FIGUEIREDO (1981) indicated that Pinguipes somnambula is a synonym of Pseudopercis semifasciata (=Percis semifasciata).

The examination of the type-specimen and description of Pinguipes somnambula, and of the original description and illustration of Percis semifasciata, confirmed the synonymy proposed by BERG (1899) and FiguEIREDo (1981). The type specimen of Percis semifasciata could not be found at the MNHN (M. Desoutter, personal communication).

Material examined. MACN 581 (1), 39² $40^{\prime} \mathrm{S}, 56^{\circ} 00^{\prime} \mathrm{W}$; MACN 6211 (2), $43^{\circ} 47^{\prime}$ S, $64^{\circ} 58^{\prime} \mathrm{W}$; MACN uncatalogued, Puerto Madryn, Argentina; MACN 6622 (1), Mar del Plata (type of Pinguipes somnambula); MACN uncatalogued (1), Atlantic coast, Buenos Aires Province; MZUSP 19223, 334ㅇ's, $51^{\circ} 42^{\prime}$ W; MZUSP

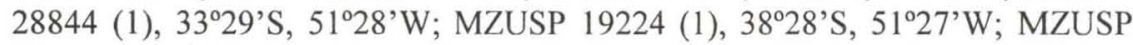

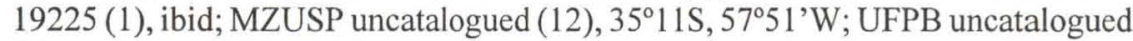

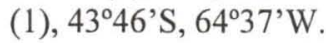

Diagnosis and description. D iv-5, 24-27; vomer with single series of 9-10 teeth; two predorsal bones; posterior margin of parasphenoid with spiny process on each side. Upper jaw with external row of 38-40 conical teeth, backed by several 
rows of villiform teeth; lower jaw with external row of 30-43 conical teeth, backed by several rows of villiform teeth. Posterior margin of preopercle slightly crenulated; posterior margin of opercle entire, with two spines on dorsal angle, covered by skin; superior spine blunt, inferior spine pointed. Total length $126.7-942 \mathrm{~mm}(260$, $336)$; standard length $126.5-832 \mathrm{~mm}(218,228)$; head length $24.8-36.8(30.0,36.8)$; snout length 9.3-15.8 $(10.6,14.1)$; horizontal length of orbit 4.2-11.7 (7.9, 7.9); bony interorbital width 2.8-5.7 (3.9, 5.7); predorsal length 27.2-58.2 $(31.6,35.7)$. First gill arch with 17-19 elongate gill rakers, with denticles on distal margin; gill raker rudiments semicircular, with numerous denticles. Pharyngeal teeth conical and numerous. Dorsal fin long, its basal length 40.2-67.7 $(60.9,75.5)$. Origin of dorsal fin on same vertical as base of pectoral fin. Anal fin long, its origin in vertical line between 8 th and 10th dorsal-fin rays; anal-fin spines flexible and short. Caudal fin with truncate margin and 17 principal rays. Pelvic fins inserted in same position as in Pinguipes, but less fleshy.

Snout, interorbital and gular regions naked; other parts of head scaly. Pectoral and caudal fins with minute scales at their bases; other fins naked.

Colour in alcohol. Dorsal half of head and body brown, ventral half light brown; six dark brown bars on dorsal part of body, the origin of the first bar in same vertical as first dorsal-fin spine; origin of last bar by the penultimate dorsal-fin ray. The first four bars reach up to ten scale rows below lateral line; other bars gradually decrease in size, the last one extends only to three scale rows below lateral line. Dorsal-fin spines darker than rays; interradial membrane of dorsal fin with dark margin and two series of dark elongate spots, one at the fin base and other at mid level. Pectoral fins light-brown, with a dark- brown semicircular area at their base; pelvic fins light; caudal peduncle width 10.0-23.5 (11.9, 14.9); caudal fin brown, with dark dorsal margin and one black oval spot on its dorsal lobe.

Colour of fresh specimens. Dorsal half of head yellow, dorsal half of body violet, ventral portions white; two longitudinal stripes on head, the upper one black and the lower one anteriorly red and posteriorly black; a series of red oval spots below the two stripes, reaching the preopercle; six black bars on body, with intermediate irregular dark spots which form two narrow longitudinal stripes. Pectoral fins yellow, pelvic fins white, anal fin light blue, caudal fin yellow with a conspicuous dark spot and several smaller spots on its dorsal lobe.

Miscelaneous data. Pseudopercis semifasciata is not common in Brazilian waters (MENEZES \& FIGUEIREDO 1985), but it is a commercially important species in Argentina (BELLISIO et al. 1979); it reaches nearly $1 \mathrm{~m}$ in length and over $10 \mathrm{~kg}$ in weight. It inhabits waters between 50 and $100 \mathrm{~m}$ of depth, and is particularly abundant in Golfo San Matias, Argentina (BELlisio et al. 1979).

Geographic distribution. From the coast of São Paulo, Brazil, to Golfo de San Jorge, Argentina. 


\section{Pseudopercis numida Ribeiro, 1903}

Figs 13-14

Pseudopercis numida Ribeiro, 1903: 41 (original description, Rio de Janeiro, Brazil). Ribeiro, 1915: 9. - Ribeiro, 1918: 146. - Fowler, 1942: 177. - Fowler, 1951a: 28. - Ribeiro, 1955: 390. - Ihering, 1968: 483. - Figueiredo, 1981: 40. - Menezes \& Figueiredo, 1985: 46.

Mugiloides numida; Roux, 1973: 153.

Type locality. Ilha Rasa, Rio de Janeiro, Brazil.

Holotype. MNRJ 2237.

Common name. Namorado.

Material examined. BMNH 1923.7.30.281 (1), Fish market, Rio de Janeiro, Brazil; MNRJ 2237 (holotype), Ilha Rasa, Rio de Janeiro, Brazil; MZUSP uncatalogued (1), $23^{\circ} 20^{\prime} \mathrm{S}, 42^{\circ} 47^{\prime} \mathrm{W}$; MZUSP uncatalogued (1), $23^{\circ} 16^{\circ} \mathrm{S}, 41^{\circ} 56^{\prime} \mathrm{W}$;

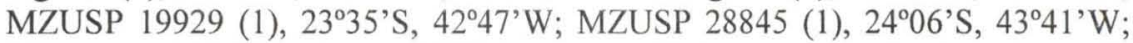
MZUSP 28846 (1), $28^{\circ} 25^{\prime}$ S, $42^{\circ} 11^{\prime}$ W; UFPB 1745 (1), Santos, São Paulo, Brazil.

Diagnosis and description. D vii, 26-28; A i-ii, 24-27; vomer with 7-8 teeth in external row and 3-7 teeth in internal row; upper jaw with external row of 31-34 conical teeth, backed by several rows of villiform teeth; lower jaw with external row of 31-36 teeth, backed by several rows of villiform teeth. Posterior margin of preopercle crenulated; posterior margin of opercle entire, with two spines on dorsal angle, covered by skin; superior spine blunt, inferior spine pointed. Total length 203-553mm $(328,338)$; standard length $172-465 \mathrm{~mm}(277,292)$; head length 26.9-38.2 (30.8, 29.2); snout length 10.3-14.6; horizontal length of orbit 5.2-9.2 $(6.5,6.7)$; bony interorbital width 3.5-6.7 $(4.9,4.4)$; predorsal length 21.6-31.9 $(28.9,28.7)$. First gill arch with $16-20$ gill rakers; gill raker rudiments semicircular, with numerous denticles. Pharyngeal teeth conical and numerous. Dorsal fin long, its basal length 58.9-82.4 $(65.2,64.3)$. Origin of dorsal fin in same vertical as base of pectoral fin. Anal fin long, its basal length 39.8-55.3, its height approximately equal to that of dorsal fin. Origin of anal fin in vertical line between 7th and 9th dorsal fin ray. Caudal fin with truncate margin and 17 principal rays. Snout, interorbital and gular regions naked; other parts of head scaly; pectoral and caudal fins with minute scales at their bases; other fins naked.

Colour in alcohol. Three different patterns were observed: (a) snout, symphyseal portion of upper lip and interorbital region grey; rest of upper lip and preopercle light brown; opercle violet; body dark grey above lateral line, light grey below lateral line and brown ventrally; dorsal fin with grey rays and spotted interradial membrane; pectoral fins light brown with grey base; pelvic and anal fins light brown; caudal fin proximally brown, distally yellow; (b) head and body dark violet dorsally, light violet below lateral line and ventrally brown; dorsal fin brown, pectoral and anal fins light brown, caudal fin dark brown; (c) head, body and fins uniformly violaceous. Colour pattern of fresh specimens is described in RIBEIRO $(1903,1915)$ and FigueIrEDo \& MENEZES (1985). The different colour patterns observed in this species possibly represent both ontogenetic and sexual variations.

Miscelaneous data. Psendopercis numida inhabits deeper waters of the continental shelf, and is commercially exploited with use of hook and line (MENEZES 
\& FIGUEIREDO 1985). The species reaches ca. $1.20 \mathrm{~m}$ in length and is considered as a first quality food fish.

Geographic distribution. From Rio de Janeiro, Brazil to the coast of Santa Catarina, Brazil (MENEZES \& FIGUEIREDO 1985). IHERING (1968) mistakenly cited this species for northern Brazil. MENEZES (1971) cited this species for the coast of Rio Grande do Sul, Brazil; this citation possibly refers to Pseudopercis semifasciata.

\begin{abstract}
ACKNOWLEDGMENTS. Several people were helpful at the various stages of this work. Without their help, this paper would not have been completed. We would especially like to thank José Lima de Figueiredo (MZUSP); we are also indebted to the following persons: Joseph S. Nelson (University of Alberta); Louise Bauchot and Mrs. Martine Desoutter (MNHN); John E. McCosker (Steinhart Aquarium, California); R.V. Melville and Mark Tollitt (International Comission on Zoological Nomenclature, London); William Saul (ANSP); Alwyne Wheeler (BMNH); Susan Jewett and Richard Vari (USNM); Hugo P. Castello and Estevan B. Oro (MACN); Karsten Hartel (MCZ); Jeffrey Siegel (LACM); Atila Gosztonyi (CONICET, Argentina); Dione, Marta and Conceição (Librarians, MZUSP). Posthumous thanks are due to India Borba, who kindly assisted the first author during her visit to the MNRJ. We also thank CNPq (Conselho Nacional de Desenvolvimento Científico e Tecnológico) for its support to this project, through a scholarship provided to the first author.
\end{abstract}

\title{
REFERENCES
}

Bahamonde, M.N. 1950. Alimentación del rollizo (Pinguipes chilensis Molina, 1782). Inv. Zool. Chil. 1 (2): 13-14.

Bahamonde, M.N. \& G. Pequeño. 1975. Peces de Chile. Lista sistemática. Publ. Ocas. Mus. Nac. Hist. Nat., Santiago, 21: 1-20.

BAILEY, R.M. 1957. Request for a ruling determining the authorship to be attributed to the various portions of the work entitled "Histoire Naturelle des Poissons" written partly by Cuvier and partly by Valenciennes and published in the period 1828-1850. Bull. Zool. Nomencl. 13: 309-312.

BART, W.J. 1852. Ichthyology. Fishes of perch family. London, Naturalist's Library, 177p.

Bellisio, N.B.; L.B. Rogelio \& A. Torno. 1979. Peces marinos patagonicos. Buenos Aires, Ministerio de Economia, Secretaria de Estado de Intereses Maritimos.

BERG, C. 1895. Enumeracion sistematica y sinonimica de los peces de las costas Argentinas y Uruguayas. An. Mus. Nac. Buenos Aires 4 (2): 1-120. 165-174.

BLEEKER, P.E.A. 1859. Enumeratio Specierum Hucusque in Archipelago Indico observatorum, adjectis Habitationibus, citationebusque, ubi descriptiones earum recentiores reperiuntur, nec non speciebus musei Bleekeriani Bengalensis, Japonicus, Capensibres Tasmanicisque. Bataviae, Types Langii \& Soc., 276p.

1863. Onziéme notice sur la faune ichthyologique de l'Ile de Ternate. Ned. 
Tijdschr. Dierk 1: 228-238.

BOULENGER, G.A. 1901. Notes on the classification of teleostean fishes. I. On the Trachinidae and their allies. Ann. Mag. Nat. Hist. 7: 261-271.

BUEN, F. DE. 1959. Lampreas, tiburones, rayas y peces en la estacion de biologia marina de Montemar, Chile. Rev. Biol. Mar. 9 (1, 2, 3): 1-200.

Cantwell, G.E. 1964. A revision of the genus Parapercis. Pac. Sci. 18 (3): 239-280.

CARVAlHo, J.P. 1950. Resultados científicos do cruzeiro "Baependi" e "Vega" à Ilha da Trindade. Peixes. Bol. Inst. Oceanogr. S. Paulo 1 (1): 97-133.

- 1956 Neopercis atlanticus meridionalis n.subsp. Perciforme da região Leste meridional do Brasil (Pisces: Mugiloidei). Bol. Inst. Oceanogr. S. Paulo 7 (1): 16-26.

CUVIER, G. 1829. Le Régne Animal. Paris, Vol. 2, 523p.

Cuvier, G. \& A. Valenciennes. 1829. Histoire Naturelle des Poissons. Paris, Vol. 3.

. 1833. Histoire Naturelle des Poissons. Paris, Vol. 9.

DevicenZI, G.J. 1924. Peces del Uruguay. An. Mus. Nac. Montevideo 11 (5): 99-290.

DevicenzI, G.J. \& D. Legrand. 1940. Album ictiologico del Uruguay. Montevideo, Imprenta Nacional, 8p.

EsCHMEYER, W.N. \& R.M. BAILEY. 1990. Genera of recent fishes, p.7-433. In: W.N. ESCHMEYER (Ed.). Catalog of the genera of recent fishes. Part I. San Francisco, California Academy of Sciences, 697p.

EvermanN, B.W. \& W.C. Kendall. 1907. Notes on a collection of fishes from Argentina, South America, with descriptions of three new species. Proc. U.S. Nat. Mus. 31: 67-108.

Evermann, B.W. \& L. Radcliffe. 1917. The fishes of the west coast of Peru and Titicaca basin. Bull. U. S. Nat. Mus. 95: 1-166.

Figueiredo, J.L. 1981. Estudo das distribuições endêmicas de peixes da Província Zoogeográfica Marinha Argentina. Unpublished Ph. D. Thesis, Universidade de São Paulo, São Paulo.

FISCHER, W. 1958. Primeras fases del desarollo del blanquillo (Prolatilus jugularis Cuv. \& Val.) Pisces. Rev. Biol. Mar. Valparaiso 8: 3-24.

Fowler, H.W. 1907. Notes on Serranidae. Proc. Acad. Nat. Sci. Phila. 59: 249-269.

1942. A list of fishes known from the coast of Brazil. Arq. Zool. S. Paulo 3 (6): 115-184.

- 1944. Los peces del Peru. Catalogo sistematico de los peces que habitan en aguas peruanas. (Continuacion). Bol. Mus. Hist. Nat. Javier Prado, Lima, $8(28 / 29): 89-126$.

. 1945a. Los peces del Peru. Catalogo sistematico de los peces que habitan en aguas peruanas. Lima, Museo de Historia Natural "Javier Prado", Universidad Nacional Mayor de San Marcos, 289p.

1945b. Description of a new genus of parapercid fishes from Chile. Rev.

Chil. Hist. Nat. 48: 25-27. 
1951a. The Brazilian and Patagonian fishes of the Wilkes Expedition, 1832-1842. Bol. Inst. Oceanogr. S. Paulo 2 (1): 3-39.

. 1951b. Analysis of the fishes of Chile. Rev. Chil. Hist. Nat. 51/53: 263-326.

GILL, T.N. 1861. Synopsis of the Sillaginoids. Proc. Acad. Nat. Sci. Phila. 13: 501-525.

-1865. On the genus Caulolatilus. Proc. Acad. Nat. Sci. Phila. 17: 66-68. . 1872. Arrangement of the families of fishes of classes Pisces, Marsipobranchii and Leptocardii. Smithson. Misc. Collect. 247: I-XX+1-49. . 1881. Note on the latiloid genera. Proc. U. S. Natl. Mus. 4: 162-164. 125-138.

GILTAY, L. 1933. Résultats scientifiques du voyage aux Indies Orientales Néerlandaises. Mem. Mus Roy. Hist. Nat. Belgique 5 (3): 1-126.

GOMON, J.R. 1980. Parapercis diplospilus (Pisces: Mugiloididae), a new species from the Philippine Islands. Proc. Biol. Soc. Wash. 94 (3): 989-996.

GosLine, W.A. 1968. The suborders of perciform fishes. Proc. U.S. Nat. Mus. 124: 1-78.

GREGORY, W.K. 1933. Fish skulls. A study of the evolution of natural mechanisms. Laurel, Eric Lundeberg, reprint 1959, 481p.

Guichenot, A. 1848. Peces de Chile, p.137-372. In: C. GAY (Ed.). Historia Fisica y Politica de Chile. Paris, Zoologia, Vol. 2.

GÜNTHER, A. 1860. Catalog of fishes of the British Museum. London, Trustees of the British Museum, Part 2, 517p.

. 1880. An introduction to the study of fishes. Edinburgh, Adam and Charles Black.

Hildebrand, S.F. 1946. A descriptive catalog of the shore fishes of Peru. Bull. U.S. Nat. Mus. 189: 1-530.

HuBBS, C.L. \& K.F. LAGLER. 1964. Fishes of the Great Lakes region. Ann Arbor, University of Michigan.

IHERING, H. VON. 1887. Os peixes da costa do mar do Estado do Rio Grande do Sul. Rev. Mus. Paulista 2: 25-63.

- 1968. Dicionário dos animais do Brasil. São Paulo, Editora Universidade de Brasília, 720p.

JENYNS, L. 1842. The zoology of the voyage of H.M.S. "Beagle". Fishes. London, Part 4, 172p.

JoRDAN, D.S. 1917. The genera of fishes. Stanford, Stanford University Press, Part $1,161 \mathrm{p}$.

-1923. A classification of fishes including families and genera as far as known. Stanford, Stanford University Press, 243p.

Koepcke, H.W. 1963. Lista de los peces marinos conocidos del Peru. Biota 4: 325-352.

Leviton, A.E.; A.E. Gibbs JR.; E. Heal \& C.E. Dawson. 1985. Standards in herpetology and ichthyology: part I. Standard symbolic codes for institucional resource collections in herpetology and ichthyology. Copeia 1985 (3): 802-832. 
LOPEZ, R.B. 1963. Problemas sobre la distribucion geográfica de los peces marinos sudamericanos. Rev. Mus. Arg. Cienc. Nat. Bernardino Rivadavia (Hidrobiologia) 1 (3): 111-135.

MANN, G. 1954. Vida de los peces en aguas chilenas. Santiago, Inst. Invest. Veter.. MCCoskeR, J.E. 1971. A new species of Parapercis (Pisces: Mugiloididae) from the Juan Fernandez Islands. Copeia 1971 (4): 682-686.

MENEZES, N.A. \& J.L. FigUEIREDO. 1985. Manual de peixes marinhos do sudeste do Brasil. Teleostei (4). São Paulo, Museu de Zoologia, Universidade de São Paulo, Vol. 5.

MENNI, R.C.; R.A. Ringuelet \& R.H. Ringuelet. 1984. Peces marinos de la Argentina y Uruguay. Catalogo critico ilustrado. Clave para la determinación de familias, generos y especies. Nombres Vulgares. Glosario. Editorial Hemisferio Sur S.A.

MoLINA, G.I. 1782. Saggio sulla storia naturale del Chile, del signor abate Giovanni Ignazio Molina. Libro IV. Vermi, insetti, rettili, pesci, ucelli e quadrupedi del Chile. Bologna.

MoRENO, C.A. \& J.H. ZAMORANO. 1980. Selectividad del alimento en dos peces bentofagos (Mugiloides chilensis y Calliclinus geniguttatus). Bol. Inst. Oceanogr. S. Paulo 29 (2): 245-249.

NAKAMURA, I.; T. INADA; M. TAKEDA \& H. HATANAKA. 1986. Important fishes trawled off Patagonia. Tokyo, Japan Marine Fishery Resource Research Center.

Navarro, J. \& G. Pequeño. 1979. Peces litorales de los archipielagos de Chiloe y los Chonos, Chile. Rev. Biol. Mar., Dept. Oceanogr. Univ. Chile, 16 (3): 255-319.

NELSON, J.S. 1984. Fishes of the world. New York, Wiley Interscience, $2^{\text {nd }}$ Ed.. . 1994. Fishes of the world. New York, Ed. J. Wiley \& Sons Inc., $3^{\text {rd }}$.

Nonato, E.F.; A.C.Z. Amaral \& J.L. Figueiredo. 1983. Contribuição ao conhecimento da fauna de peixes do litoral norte do Estado de São Paulo. Bol. Inst. Oceanogr. S. Paulo 32 (2): 143-152.

Norman, J.R. 1937. Coast fishes. Part II. The Patagonian Region. Discovery Rep. 16: $1-150$.

. 1966. A draft synopsis of the orders, families and genera of recent fishes and fishlike vertebrates. London, Trustees of the British Museum (Natural History).

PietsCH, T.W. 1989. Phylogenetic relationships of trachinoid fishes of the family Uranoscopidae. Copeia 1989 (2): 253-303.

Pietsch, T.W. \& C.P. Zabetian. 1990. Osteology and interrelationships of the sand lances (Teleostei: Ammodytidae). Copeia 1990 (1): 78-100.

PozZI, A.J. \& L.E. BorDALÉ. 1935. Cuadro sistematico de los peces marinos de la Republica Argentina. An. Soc. Cien. Argent. 120 (1): 145-189.

QUIJADA, B. 1912. Catalogo ilustrado y descriptivo de la coleción de peces chilenos y extrangeros. Bol. Mus. Nac. Chile 4 (1): 69-109.

RANDALl, J.E. 1984. Two new Indo-Pacific mugiloidid fishes of the genus Parapercis. Freshwater and Marine Aquarium Magazine. 7 (12): 41-49. 
Regan, C.T. 1909. The classification of teleostean fishes. Ann. Mag Nat. Hist. 8 (3): 75-86.

111-145.

Ribeiro, A.M. 1903. Pescas do Annie. A Lavoura 7 (417): 150-196. $1-668$.

. 1915. Fauna Brasiliense. Peixes. Arch. Mus. Nac., Rio de Janeiro, 17:

1918. Fauna Brasiliense. Peixes. Tomo V. Eleuterobranchios Aspirophoros. Physoclisti. Arch. Mus. Nac., Rio de Janeiro, 21: 7-227.

RiBEIRo, P.M. 1955. Tipos das espécies e subespécies do Prof. Alipio de Miranda Ribeiro depositados no Museu Nacional. Arq. Mus. Nac., Rio de Janeiro, 42: 389-417.

Ringuelet, R.A. \& R.H. Ringuelet. 1960. Peces marinos de la Republica Argentina. Clave de familias y generos y catalogo critico abreviado. Agro 2 (5): 1-141. ROSA, I.L. 1987. Revisão sistemática das espécies sul-americanas da família Pinguipedidae (Pisces: Trachinoidei). Unpublished M.S. thesis, Universidade Federal da Paraíba, João Pessoa, PB. 1993. Systematic study of the family Crediidae (Perciformes: Trachinoidei). Unpublished Ph. D. thesis, University of Alberta, Edmonton, Alberta.

Rosa, I.L. \& R.S. RosA. 1987. Pinguipes Cuvier and Valenciennes and Pinguipedidae Günther, the valid names for the fish taxa usually known as Mugiloides and Mugiloididae. Copeia 1987 (4): 1048-1051.

Roux, C. 1973. Résultats scientifiques des campagnes de la "Calypso" au large des côtes atlantiques de l'Amerique du Sud (1961-1962). Première Partie. 26. Poissons teleostéens du plateau continental Brésilien. Paris, Masson et Cie..

SCHNEIDER, C.O. 1943. Catalogo de los peces marinos del litoral de Concepción y Arauco. Bol. Soc. Biol. Concepción 12: 75-126.

SCHULTZ, L.P. 1960. Family Mugiloididae. Fishes of the Marshall and Marianas Islands. Families from Mullidae through Stromateidae, Vol. 2. Bull. U.S. Nat. Mus. 202: VII+1-438.

TAYLOR, W.R. \& G.C. VAN DYKE. 1985. Revised procedures for staining and clearing small fishes and other vertebrates for bone and cartilage study. Cybium 9: $107-119$.

WHITEHEAD, P.J.P. \& G.S. MYERS. 1971. Problems of nomenclature and dating of Spix and Agassiz's Brazilian fishes (1829-1831). Jour. Soc. Biblphy. Nat. Hist. 5 (6): 478-497.

Whitley, G.P. \& W.J. PhilliPS. 1939. Descriptive notes on some New Zealand fishes. Trans. Proc. Roy. N. Zealand 69 (2): 228-236.

Recebido em 08.V.1996; aceito em 22.X.1997. 